\title{
PERSUASION IN RELIGIOUS DISCOURSE: ENHANCING CREDIBILITY IN SERMON TITLES AND OPENINGS
}

\author{
Martin Adam
}

\begin{abstract}
Since the emergence of the Aristotelian idea of appeal within the framework of his understanding of poetics, the concepts of ethos, pathos, and logos have indicated the essence of what came to be labelled much later as persuasive strategies. Although persuasion seems to be present in virtually all text types and registers, in many ways it is the religious discourse that utilises persuasion as one of its pivotal instruments to convince the audience of the veracity of the doctrine presented through it. The present paper explores scripted sermons, particularly sermon titles and opening passages, in terms of the persuasive strategies employed. The main emphasis is placed on how particular linguistic realisations of persuasion enhance the credibility of the message.
\end{abstract}

\section{Keywords}

persuasion, credibility, genre, sermon, religious

\section{Introduction}

Persuasive texts constitute an essential layer of many types of discourse: both in spoken and written English, across styles and registers, and across genres, cultures and time (Cotterell \& Turner 1989: 230-248, Dillard \& Pfau 2002, Virtanen \& Halmari 2005: 3). Inevitably related to peoples' beliefs and convictions, persuasive strategies are necessarily adopted by users to highlight crucial points, to present ideas as well as to procure one's arguments with the intention to convince others. Persuasion has always been an integral aspect of human interaction that operates in different professional and linguacultural settings; it is therefore inherently context-dependent and audience-oriented (Virtanen \& Halmari 2005: 6-7).

As an abstract and somewhat intangible, albeit existing and highly effective, phenomenon, persuasion seems to be born of an intricate mycelium of a whole complex of both linguistic and extra-linguistic aspects (Bell 1997: 151-153, Cialdini 1993, cf., e.g. Halmari \& Virtanen 2005, Dillard \& Shen 2013, Bhatia \& Bremner 2014). What is it that makes a piece of language persuasive? What do addressors do in order to make their utterances credible and potent enough to convince their addressees? What are the particular linguistic tools that foster persuasion in human communication? 
As part of a larger-scale research project on persuasion in English and Czech specialised discourses, the present paper aims to explore the persuasive strategies adopted in scripted sermons. Sermons, as a rhetoric religious genre of great significance and text type sui generis, will be viewed from the angle of their persuasive haecceity. Specifically, the paper will focus on different ways in which persuasion is conceptualised in this persuasive discourse (namely sermon titles and sermon openings), attempting to identify and categorise the rhetorical strategies and linguistic realisations of persuasion and to shed light both on how persuasion is both overtly and covertly manifested in the texts under examination and on what linguistic means contribute to the overall persuasive character of the discourse of sermons. On top of that, the paper will also examine how credibility, i.e. the ideology-related phenomenon, especially significant in religious discourse, is enhanced in the corpus and in what ways it is made prominent in the rhetoric of sermons.

\section{Material and method}

As the paper deals with a qualitative (and partly quantitative) analysis of a corpus of scripted sermons, it will largely utilise the analytical framework and methods of discourse and genre analyses (e.g. van Dijk 1977, Schiffrin et al. 2001, Swales 1990, Bhatia 1993). In terms of the quantitative examination (statistical data), selected tools of corpus analysis will be used, the primary software being Sketch Engine.

The research corpus gathered for the purposes of the present paper (REL-ENG) comprises 43 individual sermons in English that were randomly selected from online sources, each of a comparable length. The sermons were delivered by 20 different native speakers of English (anonymised for research purposes). The corpus set amounts to ca. 100,000 words in total. All sermons represent the genre of scripted sermons, which means that these were originally written by the authors to be delivered in a church environment and later published on the website of the church or on the preachers' blogs. Individual examples adduced below are marked with unique codes that consist of the corpus code and the relevant number of the corresponding sermon in the corpus (i.e. REL-ENG-1 to REL-ENG-43).

In order to make the selection representative and, at the same time, thematically comparable, I decided to focus on a single theme only, rather than to deal with a multifaceted complex of sermons; to be more specific, the messages under investigation are equivocally related to Advent and Christmas. Furthermore, to enhance the homogeneity of the corpus, all the sermons are intentionally recruited from mainstream Protestant denominations traditionally established in 
the United Kingdom and the United States of America, viz. Baptist, Presbyterian, Methodist and other free Protestant denominations. The point is that other major branches of Christian churches, such as the Roman Catholic Church or Orthodox Church, would display differences in terms of the genre of sermon based on the specific role homiletics plays in the given denomination; with a certain degree of simplification, it is possible to see that unlike the Protestant tradition, which accentuates the sermon within the church service as the mediation of the Word of God, the other denominations seem to place an emphasis on the liturgy itself along with the Eucharist as the centrepiece rather than on the homiletic message (Allen 1992, Robinson 2014). Chronologically speaking, the selected messages broadly represent the last three decades. Thus, the corpus gained is believed to present a relatively uniform set of reconcilable texts, both in the formal and thematic senses.

\section{Religious discourse: Objectives}

Religious discourse in its entirety comprises a multi-layered set of different genres, registers and text types. No matter what the differences are, all items that can be labelled religious are closely related to the basic purpose of religious communication: to create, mediate and reflect ideology in order to persuade the reader of the veracity of the Christian doctrine (Cotterell \& Turner 1989: 26-33, van Dijk 1998: 317). As an effective vehicle of ideology dissemination, persuasion is the flagship of religious texts in both the linguistic and extra-linguistic senses. In line with this claim is van Dijk's argument, "discourse has a special function in the expression, implementation and especially the reproduction of ideologies, since it is only through language use, discourse or communication [...] that they can be explicitly formulated" (van Dijk 1998: 316-317). In other words, by means of persuasion the two-fold mission of religious discourse is fulfilled: the audience is persuaded of the church's teaching and Christian ideology is legitimised.

Socio-culturally speaking, Ghadessy views a text as "part of the enacted discourse of a socially defined group, a culture or speech community" (Ghadessy 1988: 65). The existence of 'audience' is logically closely interconnected with the possibility of interacting and, eventually, persuading (Virtanen \& Halmari 2005: 7). This can be applied to Christian believers, who form an ideologically distinctive community with its own culture, system of signs, and way of communication. Apart from discourse itself (verbal realisation of ideology), ideology should also be associated with two other dimensions: society and (social) cognition. Such a multidisciplinary approach seems to capture the whole complex of ideology in its entirety (Bell 1997, van Dijk 1998). Although the 
paper is concerned predominantly with linguistic discourse proper, the other two aspects of ideology will also be taken into consideration.

\subsection{The discourse of sermons}

By definition, a sermon (also known as a homily, particularly within the Roman Catholic Church) is "discourse from a pulpit" (Onions 1996: 812). It is a religious speech delivered typically in a church building, usually from a pulpit or an ambo (L. sermo = discourse). Sermons constitute a part of secondary religious discourse, which is represented by writings that comment on, further discuss, disseminate or interpret the primary religious texts (above all the Bible), such as biblical commentaries (i.e. a distinct genre of theological literature interpreting the Scriptures) or homilies delivered in a church.

Sermons typically take one of two forms: topical/thematic sermons (the preacher draws on various Bible passages to corroborate a thesis about a particular theme), and expository/text sermons (a single passage of the Bible is used as a jumping-off point to discuss a particular thesis; as a rule, text messages follow the text in a verse-by-verse fashion, moving from the text to application (Robinson 2014: 11-15, Allen 1992). The typical structure of protestant sermons is usually as follows: OPENING - BIBLE READING - MAIN BODY (further structured into EXEGESIS = context analysis along with critical explanation of the text; HERMENEUTICS = interpretation; and APPLICATION) - CONCLUSIONS (e.g. Garlock 2002: 39, Fee \& Stuart 2003: 13-25; cf. Robinson 2014: 71ff). Individual points may be enriched and further exemplified by the preacher's illustrations, personal digressions, intertextual allusions, and the like. All the aspects mentioned above may vary according to the audience present, their experience, and their cultural and spiritual modes of knowing.

Seen from the perspective of sociolinguistics, the sermon is necessarily connected with the audience it is delivered to (van Leeuwen 1996, Bell 1997). Within Halliday's systemic understanding of register (Halliday 1978), register is an aspect of the context of situation. Thus, speaking of the genre of sermons, the following can be observed: the church setting forms the field, the preacher, the pastor and the congregation represent the level of tenor, and the mode is usually spoken (formal, polite) or written. The characteristics of the religious discourse reflected in sermons in the light of different literary genres are discussed by Crystal and Davy (1969: 148-149), who point out that not all religious genres fall into the category of the language of the liturgy. For example, the language of sermons has stylistically more in common with other varieties of public speaking (ibid.). 
At this point, it is necessary to elucidate one aspect of the analysis that is, as a matter of fact, inevitably related to the very nature of sermons. As has been noted above, the present research deals with the scripted version of sermons that were originally either meant to be read out loud at church or that were first delivered at the pulpit and then written down for filing or publication purposes. Apart from non-prosodic linguistic characteristics, there is of course an entire set of prosodic features determining the style of the discourse of sermons, such as pitch, tone, volume, duration, pausing, etc., when they are being uttered or listened to via a previous recording. Obviously, this category concerns exclusively the spoken form of religious messages (similarly to sermons, this would be applicable to Bible readings or oral prayers, for instance). Indeed, in the course of genuine, on-the-spot interaction in real time, the prosodic features contribute to further distinction of genres or modalities of the discourse, and are even able to identify group membership. Thus it is the whole array of suprasegmental linguistic features that makes the style of spoken English so prominent in religious discourse; nevertheless, in the scripted sermons analysis, the suprasegmentals are logically disregarded.

\section{Persuasion}

The purpose of religious writing, including sermons, is naturally connected with persuasion, and, as a matter of fact, (religious) ideology. Carter and Nash (1990: 21) define ideology as "a socially and politically dominant set of values and beliefs which are [...] constructed in all texts especially in and through language". In their study, they sub-divide the participants of communication with respect to style and ideology into "the interested writer" and "the interested reader" domains - "writers are concerned in varying degrees with: first of all persuading readers to pick up the text and to read it; second, they are concerned with prompting readers to act in accordance with a set of behaviours" (Carter \& Nash 1990: 50-51; italics mine). The reader, on the other hand, should be challenged to take over and accept the values, i.e. be convinced and, eventually, persuaded. Also in the case of sermons, the linguistic means serve as a vehicle for communicating the message; Carter and Nash speak of the fact that "ideology is encoded in the linguistic organisation of the text" (1990: 59). It should be noted that unlike manipulation (i.e. ideology imposed on 'passive victims' whose destiny is to believe or act as they are told, e.g. in medial or political discourse), in the case of persuasion the audience may participate actively in the persuasive process and are free to believe or act as they please, depending on whether or not they accept the arguments of the persuader (Mulholland 1993, van Dijk 2006). 
As mentioned above, persuasion, owing to its multidisciplinary nature, must be approached from a number of different perspectives, the common denominators being the indispensable reflection of the dialogic and interactive nature, and its cultural, social and situational dependency that determines the choice of language means. The authors who explore human communication (e.g. Perloff 2010) see persuasion as "a symbolic process in which communicators try to convince other people to change their attitudes or behaviours regarding an issue through the transmission of a message in an atmosphere of free choice" (ibid.: 12); they naturally point out the cultural dimension and interactive character of the process. In the realm of rhetoric, scholars (e.g. Connor 2004, Hogan 2013) approach persuasion as part of the more general notion of argumentation which is actually typical of almost all discourses and is used with the ultimate goal of persuading. Finally, linguistic studies on persuasive language examine the linguistic manifestations of persuasive discourse in different genres (e.g. Halmari \& Virtanen 2005, Dillard \& Shen 2013). Virtanen and Halmari (2005: 5), for instance, define persuasion as a communicative purpose conveyed by various rhetorical strategies and related "linguistic choices that aim at changing or affecting the behaviour of others or strengthening the existing beliefs and behaviours of those who already agree, the beliefs and the behaviours of persuaders included".

Generally speaking, persuasion across genres and discourses can manifest itself by means of a distinctive set of persuasive strategies. According to their nature, persuasive strategies are classically understood to fall into the broader categories of individual persuasive features, such as identity construction, stance and evaluation, dialogicity/engagement (i.e. appeal to the reader/hearer), and various types of intertextuality, which in effect add to ethos building (Halmari $\&$ Virtanen 2005, van Leeuwen 1996). In order to achieve the intended persuasive effect in their communication, authors adopt an array of different methods and approaches, whether deliberately or subconsciously, usually mingled in a fusion. Generally speaking, persuasion is typically manifested either overtly, i.e. via explicit linguistic realisations (e.g. use of imperatives, reiteration, modality, ways of greeting and address, choice of personal pronouns, use of questions, etc.), or, alternatively, in a more or less covert manner (i.e. various rhetorical strategies, in which persuasion is more implicit, such as employment of emotions, some interactive features, humour, etc.) (Cotterell \& Turner 1989: 294-299, Dillard \& Pfau 2002, Hogan 2013, cf. van Leeuwen 1996). In this paper, a selected set of both overt and covert features will be discussed.

Furthermore, the essence of the phenomenon of persuasion may be aptly explicated by means of the three classical types of Aristotelian appeal to the audience (aptly summarised e.g. in Virtanen \& Halmari 2005: 5-6, Hogan 2013: 
2-5), namely: (i) ethos, i.e. the ethical "voice of the persuader, the linguistically mediated message of her or his believability, reliability, and competence" (Virtanen \& Halmari 2005: 5), encompassing, for example, direct appeal, sharing personal experience, claiming common ground/past experience, narrative of belonging, narrative of achievements, us and them, building speaker credibility on the basis of authority/expertise, humour, etc.; (ii) pathos, which represents the emotional appeal to the audience (perhaps not typical of specialised professional discourses, but nevertheless quite crucial in the area of religious discourse); (iii) logos, i.e. the appeal to the rationality of the audience, for example, through presenting the present/future as a natural consequence of the past, causality mechanisms, reference to statistics/facts, experimental proof, exemplification (analogy and metaphor), etc. (cf. also van Leeuwen 1996, Connor \& Moreno 2005, Sperber et al. 2010).

\section{Analysis}

As outlined above in the theoretical framework, persuasion can be examined from many angles, at different levels of language and with the adoption of different approaches; the complex mosaic of persuasive discourse can only be uncovered on the basis of a thorough and multifaceted research. Since the present study represents the introductory, mapping stage of the project, the aspects under investigation are necessarily selective.

Even though the dominant load of information as well as the core of persuasive power is logically communicated through the main body of each sermon, one of the crucial moments of a sermon delivery seems to be encoded in its very beginning; it is the opening part of the message that has the unique chance to capture the audience's attention and to highlight the main idea, thus creating a necessary starting point for the sermon proper. Inspired by this premise, for the purpose of this preliminary qualitative (and partly quantitative) research, the following aspects of persuasion will be scrutinised in the subsequent sections of the paper: the choice of sermon titles and sermon openings and the particular linguistic features that facilitate the credibility of the sermons. Finally, generalising conclusions will be drawn and possible new vistas of research indicated.

\subsection{Sermon titles}

Inconspicuous though it may seem, the choice of a fitting and appropriate title for a sermon is a vital step in the whole process of preparing a homiletic message. This definitely holds true both for the sermons published ex post, i.e. after they have been delivered at church, and for those cases when a sermon is 
first advertised in the church bulletin, noticeboard or on the church website and only then delivered. In both the cases it is the title that promotes the content of the sermon, stimulating the interest of the audience. Some professionals even argue that without a title a sermon is not complete and, as a matter of fact, cannot be fully effective (Garlock 2002: 32, Charles 2015). Needless to say, a suitable title may add to the overall persuasive effect of the whole sermon, indicating the gist of the message in a nutshell as well as triggering the congregation's attention. Charles (2015) does not hesitate to claim that a good title, being the first impression the congregation gets of the message, provides the sermon with identity.

In the following discussion, the 43 titles extracted from the corpus data will be now examined with regard to their basic linguistic features and different rhetorical devices employed - see the statistical outline in Table 1 below:

\begin{tabular}{|l|l|l|}
\hline Sentence type & Raw No & $\%$ \\
\hline Declaratives & 32 & 74.4 \\
\hline Interrogatives & 7 & 16.2 \\
\hline Imperatives & 2 & 4.7 \\
\hline Exclamatives & 2 & 4.7 \\
\hline Total & 43 & 100.0 \\
\hline
\end{tabular}

Table 1: Sentence types in sermon titles

As regards individual sentence types (and discourse functions respectively), seven titles out of the total 43 represent interrogatives, e.g. WHY DID JESUS CHRIST COME To EARTH? (REL-ENG-12), two exclamatives, e.g. THE KINGDOM OF HEAVEN IS AT HAND! (REL-ENG-14), two imperatives, e.g. EXPECT A MIRACLE (REL-ENG-1), and the rest (almost 75\%) falls into the category of declaratives, such as WHEN KINGS BOW (REL-ENG-7). Whereas the imperatives represent an overt, explicit expression of persuasive power imposed on the audience, the interrogatives, typically rhetorical questions, implicitly achieve the same; as interrogative phrases - in their essence - usually embody universal existential questions related to one's faith, the resulting rhetoric is deeply ethos-empowered: WHY WAS JESUS BORN? (REL-ENG-11) or WHAT CHILD IS THIS? (REL-ENG-20). Some items may be seen as directly thought-provoking or even provocative in the true sense of the word, abandoning the realm of rhetorical questions, for instance WHAT IF WE RETHINK WHAT WE ARE CELEBRATING? (REL-ENG-37) 
or WHEN DID CHRISTMAS GET SO COMPLICATED? (REL-ENG-38), apparently supporting dialogicity of the sermon interaction. Finally, a relatively large number of statements seem to be interconnected with the authors' frequent inclination to promote doctrinal truths through declarations of different sorts: CHRIST WILL RETURN (REL-ENG-15) or THE LIGHT STILL SHINES (REL-ENG-23), and many others; in this respect, such simplistic and straightforward declarations resemble slogans observed in marketing strategies and advertising. The overall makeup along with the ratio of sentence types used in the titles testifies to a rather restrained choice of titles; they usually summarise the main idea of the sermon.

Syntactically speaking, 21 out of the titles analysed (almost 50\%) are constituted by phrases, e.g. SCANDALOUS LOVE (REL-ENG-43); the rest are represented by sentences, such as THE ANGELS ANNOUNCE THE GOOD NEWS (REL-ENG-34), out of which six titles contain a non-finite verb form, such as FINDING THE TRUE MEANING OF CHRISTMAS (REL-ENG-35). Five titles (and the corresponding sermons) are parts of a series, which is always implicated by a common denominator in the individual sequels of sermons, such as ADVENT: THE NEED (REL-ENG-26), ADVENT: THE PROMISE (REL-ENG-27), ADVENT: THE ANNOUNCEMENT (REL-ENG-28), etc.

In terms of figures of speech and other poetic devices employed, the corpus data are quite varied. A direct quote taken from the Scriptures (sometimes a direct speech citation) seems to be a favourite one: WE HAVE SEEN HIS STAR (RELENG-22); to believers, such intertextual reference naturally serves as a genuine link to the Bible, which adds authority to the topic, especially if the quote gives Jesus's direct words, such as in BEHOLD, I COME QUICKLY (REL-ENG-16). In some cases, intertextuality is manifested through an allusion rather than a direct quote and, as a result, the author utilises a pun or a periphrasis, cf. THE THREE WISE WOMEN OF CHRISTMAS (REL-ENG-4), sometimes with an unexpected and surprising impact on the hearer/reader, i.e. the rhetorical figure of paradox: UNHAPPY HOLIDAYS aT CHRISTMAS (REL-ENG-33). Some titles purposefully contain a practical application and thus resemble a manual title in a way: THE GREATEST GIFT THERE EVER WAS AND HOW YOU CAN RECEIVE IT (REL-ENG-13). Metaphor, as one of the classic rhetorical devices, is also used: CHRISTMAS PUTTING OUT THE WELCOME MAT (REL-ENG-10) or BOILS AT CHRISTMAS (RELENG-17). In the title of REL-ENG-30, an example of hyperbole is found: 10,000 LITTLE MOMENTS: TRADING ONE DRAMATIC RESOLUTION FOR TEN THOUSAND LITTLE ONES.

To achieve an up-to-date and more personal effect, preachers may use a modern phrase (that actually deliberately violates the ancient spirit of the text, evoking a present-day conversation instead): HAPPY BIRTHDAY, JESUS! (REL- 
ENG-39), JESUS' WISH LIST (REL-ENG-40), or MEET MARY (REL-ENG-42), etc. The modern flavour in combination with the serious content of the message and the biblical support at hand obviously results in an intentionally humorous effect. This somewhat unusual yet fruitful strategy inevitably results in easier communication; by lightening the atmosphere, the preacher both gets closer to his or her audience and also makes the message more personal, human-like, and so more readily accessible. To express it in sermon terminology, humour effectively prepares the soil for the seeds to be sown in the steps to come.

From the point of view of lexicon, at least three relevant - though rather predictable - points should be made. First, there are just a few titles which do not carry a word typical of Christian religious discourse - specific vocabulary such as SALVATION, FAITH, GRACE, JOY, GOOD NEWS, LOVE, ANGEL, LIGHT, and the like, are used excessively. Second, many titles in the corpus manifest lexical items that have a connection to the idea of totality, maximum degree phenomena or perfection, including superlatives: FULLNESS, SURETY, TRUE, THE GREATEST, etc. Such elements, in harmony with the overall persuasive character of the sermons, seem to corroborate the ideological reading of the religious message, showing the Christian doctrine in a crystal-clear way as well as in the best possible light. Third, two of the titles under discussion display a triplet of entities, following in the classic footsteps of classic rhetoric, viz. the golden "rule of three" (a triad) adopted not only by ancient rhetoricians. Such three-fold structure of a sermon as reflected by their titles is clearly observable, e.g. in THREE SCENES IN HISTORY (REL-ENG-9) or THE THREE WISE WOMEN OF CHRISTMAS (REL-ENG-4), not to speak of the actual structure of most sermons as such.

As apparent from the analysis above, along with other strata of the language used (be it syntactic structure or the employment of figures of speech), without any doubt it is the choice of vocabulary that co-builds the persuasive spirit of the sermon titles. As a rule, in the sermon titles alone, the audience/readership is thus confronted with a carefully structured, well-thought out and ideologically rich material that not only summarises the essence of what the sermon is going to be about but also draws the congregation's attention to it. In many senses, the sermon title constitutes a principal determinant of the sermon: by revealing the content yet to be presented and, at the same time, determining the direction in which the audience's attention is to be drawn, it exposes the milestones of the upcoming message and actually anticipates its mission; thus, it exploits logos. Furthermore, via linguistic creativity such as plays on words, puns, humour, intertextual allusions and a whole arsenal of poetic devices, it affects the audience's emotions and serves as a lure for the potential receivers, stirring pathos. Finally, through stating doctrinal truths it imbues the future sermon with 
credibility, and appeals to the audience, hitting the string of ethos. In other words, a sound sermon title is one of the most effective instruments that operates at the service of persuasion.

\subsection{Sermon openings}

Contrary to sermon titles that may or may not be actually uttered or even referred to during the sermon, every sermon undoubtedly needs an appropriate opening, i.e. the very first passage of words that the preacher says.

Even though a sermon can be opened in many different ways, the purpose of the introduction is always the same. In this respect, being analogous to some aspects of sermon titles, sermon openings typically aim to capture the attention of the audience almost immediately, to introduce the narrowed subject of the sermon, and to build a rapport with the audience and whet an appetite for God's Word (Robinson 2014: 16-20). Needless to say, the climax of the sermon, i.e. "the most important arguments of a persuasive message are presented at the end of the message" (Shen \& Bigsby 2013: 24); the climax structure may be altered by an anti-climax structure, which actually causes the same effect, though it adopts an opposite direction of argumentation.

Whereas some preachers appear to be keen on beginning their messages on a personal note (e.g. telling their own story or sharing someone else's experience, telling a joke, etc.), others prefer starting their sermon in a more traditional manner (e.g. by reading the biblical passage that they will examine and interpret in the minutes to come). What typically comes next is the outline of the sermon itself, establishing the main point, structure, and objectives of the message. Another significant moment of the opening is represented by placing the biblical passage and/or the topic of the sermon in context, both within the Bible, a broader topic that is currently pursued, and within the possible homiletic plan of the church or congregation (Garlock 2002: 36). It is widely believed that the sermon opening is also a good opportunity to explain the historical and literary context of the biblical passage to be examined and thus it can show how the text correlates with the larger theme of the related scriptures (Garlock 2002: 32-34, Charles 2015).

What follows is an outline of the content and structure of the sermon openings stipulated by the corpus data summarised in Table 2 below: 


\begin{tabular}{|l|l|l|}
\hline Type of content & Raw No. & $\%$ \\
\hline Providing biblical context & 14 & 32.6 \\
\hline Reading out the Bible passage & 9 & 20.8 \\
\hline Referring to liturgical year & 8 & 18.6 \\
\hline Other sources (magazine, song lyrics, etc.) & 8 & 18.6 \\
\hline Personal experience & 2 & 4.7 \\
\hline Asking rhetorical questions & 2 & 4.7 \\
\hline Total & 43 & 100.0 \\
\hline
\end{tabular}

Table 2: Content of sermon openings

As is obvious from Table 1, most sermons under investigation (almost 33\%) are opened with the preacher providing a wider biblical context for the sermon that is just about to start. Typically, such introductions remind the congregation of what the topic was last time or refer to the textual context, specifying the position of the biblical passage to be discussed shortly. Alternately, sermon openings may refer to a particular moment/period of the liturgical year (such as Advent and Christmas in this case), often followed by a personal account on the part of the preacher or a wider biblical context and doctrine (cf. (1), (2) and (3) below; NB: All examples in Section 5.2 present the actual starting passages of the sermons; the elements in question are underlined).

(1) In this series we're studying the story of Jesus' birth in the gospel of Matthew. In Matthew's narrative ancient promises and hopes are fulfilled. The heavens speak of a Ruler for Israel. King-makers arrive with remarkable gifts. And finally, as we will read in the text before us, the undeserving die, foreshadowing the cross looming in the future. (REL-ENG-23)

(2) Each Gospel's record of the life of the Lord Jesus Christ gives us a different perspective on the life of Christ. Luke's Gospel begins with the mirage birth of John the Baptist to Elizabeth and Zacharias. (1:5-25) There is a reason the account starts with John the Baptist's birth. Beginning in verse 26, we are given the account of [...] (REL-ENG-12)

(3) Christmas has different meanings for each one of us, but family gatherings, good food, friends, travel, shopping, ball games, exchanging of gifts and religious celebration still seem to be part of almost everyone's Christmas celebrations. Last week, [...] (REL-ENG-25) 
The second most frequent way of opening the sermons is reading out the Bible passage that is going to be elaborated on in the main body of the sermon. Such readings, whether short or long, are typically done abruptly, without any prior introduction - the congregation (the reader) is thus directly engaged in the presentation of God's Word. As a rule, the reading proper is directly followed by the Bible reference of the passage, and then there may come a personal account, the context specification, or a reference to another source (such as a historical event, relevant statistics, and the like). In this respect the Bible reading usually fruitfully combines with other opening types (including asking rhetorical questions, etc.). See (4) and (5) below:

"Glory to God in the highest, and on earth peace among those with whom he is pleased!" (Luke 2:14) I live at the edge of Chinatown in Philadelphia, and in the winter to avoid the cold, I cut through Macy's to get to where Ineed to go. (RELENG-28)

"But when the fullness of the time was come, God sent forth his Son, made of a woman, made under the law, to redeem them that were under the law, that we might receive the adoption of sons." (Galatians 4:4-5) Last week we preached a message addressing the question of "Who was the Baby in the Manger?" Today we will look at [...] (REL-ENG-3)

A relatively high number of sermon openings provide the audience, perhaps somewhat surprisingly, with a particular account based on other sources, such as journal articles, papers, statistics, song lyrics, poems, etc.). These openings contain facts, for example, proper names of people and places, dates, historical references etc., and are typically presented either as personal memories or as information extracted from a source in order to provide a suitable exposition; see (6), (7) and (8) below:

(6) Years ago, following their church's late night Christmas Eve service, Harriet Richie's family decided to stop somewhere for a late-night bite to eat. The only place open that late on Christmas Eve was a truck stop at a nearby interstate junction. (REL-ENG-43)

(7) I think we are all familiar with the events at the beginning of WWII, when the Philippines were about to fall to the Japanese. Roosevelt ordered General Douglas MacArthur to evacuate his staff immediately to Australia. MacArthur was very upset [...] (REL-ENG-16)

(8) On 28th July 1978 Louise Brown was born. News of her birth in Oldham, England, reverberated in around the world on television and radio. She was hailed as the "miracle baby". Louise was the first baby to be born in a test tube outside the mother's womb. (REL-ENG-2) 
In some sermons, the opening is actually constituted as an outline of doctrinal points (even if not necessarily formulated in theological terms but a rather casual manner), to which the current topic belongs or from which it stems. In such opening passages, the preacher summarises what the Bible says in terms of the message to be delivered and, by means of revision, also provides a simple (sometimes structured, indented or bulleted) compendium of related Bible passages, principles and teaching. Such declarative sentences represent a direct and explicit set of lexically dense - and often reiterative - statements. On top of that, the declarations usually apply other poetic devices and figures of speech, such as alliteration, which undoubtedly adds to the slogan-like, declarative nature of such statements; see (9) below:

(9) The appearing of Jesus on earth made such an impact that from that moment onwards all history is judged in relationship to him.

Celebrities of all kinds have crossed the stage of human history and made little difference.

But by Jesus Christ all men are judged and their destiny determined.

A man may make other poor decisions and be temporarily worse off, but if he decides wrongly about Jesus Christ he is eternally worse off.

Jesus Christ has the answer to depravity, despair, demonism, death, discouragement, defeat, and dilemma, to name but a few! (REL-ENG-4)

Finally, to complete the picture, the following ought to be said: the linguistic realisations of persuasion are also undoubtedly reflected at the lexical level. Apart from the obvious discursive techniques such as posing questions, using imperatives etc., persuasion is boosted through a whole set of lexical aspects. In the corpus, it is possible to trace a number of instances of lexical reiteration, relexicalisation or parallel expressions that seem to enhance the high degree of semantic clarity; the religious concepts and categories especially are presented in an equivocal, straightforward manner. What seems to testify best to the clearcut terminology used in the sermons is the set of keywords - below (Table 3) is a SKetch Engine-driven Top 7 outline of keywords with the exclusion of grammatical words, personal pronouns treated separately. As visible from Table 3 , the items with the highest absolute frequency of occurrence (counted per 100,000 words) are unanimously related to deity, faith and religion. In the case of the personal pronouns used, these manifest an overt tendency to interaction and dialogicity of persuasion; the capitalised $\mathrm{He}$ refers to Jesus Christ. 


\begin{tabular}{|l|l|l|l|}
\hline \multicolumn{2}{|l|}{ Lexical words } & \multicolumn{2}{l|}{ Pronouns } \\
\hline God & 1,047 & you & 817 \\
\hline Jesus & 600 & we & 697 \\
\hline Christ & 427 & I & 664 \\
\hline Christmas & 412 & his & 547 \\
\hline Lord & 338 & He & 528 \\
\hline life & 307 & us & 447 \\
\hline faith & 262 & all & 475 \\
\hline
\end{tabular}

Table 3: Top 7 Keywords (per 100,000 words)

Moreover, credibility is definitely also enhanced by a number of credibility boosters at the lexical level, viz. intertextual references and persuasive discourse markers. To a certain extent, the intertextual features in sermons have been thoroughly discussed above; the data under scrutiny supply, nevertheless, a remarkable set of lexical hits that testify to the authors' urgency to appeal to the readers' knowledge of the matter (you know, as we all know, it is known, obviously, clearly, evidently, surely, etc.) or to refer repeatedly to an authoritative source, be it the Bible or particular biblical figures (Jesus, Apostle Paul, etc.). It is in particular the Scripture itself that appears to act as the most reliable support for a preacher's statement, providing both evidence and persuasive power. Prototypically, such an explicit appeal to trustworthiness is linguistically construed by means of the following pattern: AUTHORITY + VERBUM DICENDI (+ DIRECT OBJECT) + DIRECT QUOTE (such as The Bible tells us (that)... / As the apostle Paul says, ***...). Whereas the array of authorities given is relatively limited (the Bible, Jesus Christ, God, the Apostle Paul), the verbal elements used are more diversified; Table 4 below gives the phrases whose frequency proved to be the highest: 


\begin{tabular}{|l|l|}
\hline Phrase & Abs. \\
\hline$\ldots$ says /said, $* * *$ & 301 \\
\hline$\ldots$ tells / told (us) (that) $* * *$ & 115 \\
\hline$\ldots$ teaches / taught (us) (that) $* * *$ & 11 \\
\hline$\ldots$ speaks / spoke (of) $* * *$ & 9 \\
\hline$\ldots$ has so much to say (about) $* * *$ & 5 \\
\hline$\ldots$ gives (us) an answer (to) $* * *$ & 4 \\
\hline
\end{tabular}

Table 4: Verba dicendi operating in persuasive phrases

By far the most preferred phrase is evidently that employing the verbs say or tell, i.e. the most neutral, and, at the same time the most common types of verba dicendi. It seems that this tendency is linked to implicit persuasive potential: the main emphasis is placed on the authority itself rather than the precise manner in which the message is communicated.

\section{Discussion and conclusions}

The analytical part of the paper has focused on a variety of aspects of persuasion manifested in sermon titles and sermon openings and their particular linguistic realisations. In effect, the texts under examination seem to have a number of features in common; it is possible to observe a certain pattern: the opening passages of sermons seem to enhance their reliability and, consequently their persuasive power, through the following strategies:

(i) By introducing the necessary coordinates for the audience, mostly formed by the presentation of the context of the sermon (textual/theological/situational/ liturgical) with the intention of ensuring clarity, guaranteeing an equivocal understanding of the message (which is vital for successful communication of the doctrine). Clarity, being a quintessence of Aristotelian concept of logos, i.e. the appeal to the rationality of the audience, is further facilitated by lexical means, such as reiteration, parallelism, and emphasis on focal vocabulary related to the topic - the message conveyed is thus presented in a transparent and straightforward way.

(ii) By employing intertextual features as a means of supporting facts of different kinds, be it hard data (statistics) or other sources (quoting names, dates, newspaper/magazine citations, etc.) to provide a solid ground for the message 
and evidence of its credibility (it is true and it is known - here is the tangible proof); intertextual support of various sorts, appealing in the spirit of logos in particular. Regarding ethos, the intertextual aspect is rendered especially by personal stories as well as practical illustrations based on other sources: these enable the preacher to explain practically what has been/will be said, to make the message more intelligible to the audience as well as to enliven the sermon (incidentally, a similar approach is typical of Jesus's parables; cf., e.g. Cotterell \& Turner 1989: 307ff), thus implicitly appealing to the audience's ethical values. Shen and Bigsby (2013: 21), in relation to their classification of the message content, speak of 'analogical evidence' that utilises "analogies to support a claim, comparing one idea/situation to another". The personal tones mentioned above represent 'testimonial evidence', which "uses a person's personal experience, eye-witness account, or personal opinion to support the claim" (ibid.). To secure the highest possible degree of trustworthiness, the Bible itself is often cited: it is the Scripture, the Word of God with its infallible doctrine, that is taken for granted by believers and prototypically cited both to provide the text for further analysis and to ensure an ultimate authority ("this is how God himself sees this and how He revealed that in his Word..."); all that is said in the sermon is, as it were, mirrored and continually assessed against the background of the Bible, and hence ultimately legitimised.

(iii) Last but not least, the analysis has shown that one of the techniques that may play a pivotal role in persuasion, especially in its pathos, is an emotional appeal to the audience. It is typically mediated via affect and emotions manifested in (or triggered by) the discourse, and, effectively reinforced in juxtaposition with intertextual references to formal credible sources (hard data or the Bible). As has been demonstrated, in the case of sermon titles and openings it is especially humour in the widest sense of the word that is definitely capable of building bridges between the speaker and his or her audience, making the message more down-to-earth and accessible (cf. Dillard \& Seo 2013). (Incidentally, to my knowledge, unlike Czech tradition and customs, this rather light-hearted treatment of serious matter in sermon titles - as well as sermon openings, in which even jokes and anecdotes are apposite - seems to be quite distinctive in the area of Anglo-Saxon homiletic culture.) In the remaining parts of sermons, a whole scale of other emotions may undoubtedly be ignited of course, including sentiment, sympathy, compassion, excitement, sadness, anxiety, guilt, and the like; these serve for instance to encourage the believers to strive for a godly life, to draw inspiration from the life of Jesus and other biblical characters, to realise and accept spiritual truths, to adopt Christian principles, but also to induce fear, to warn, to threaten, etc. What also adds a sense of novelty to the present 
contribution to discourse studies is the universality of religious discourse in terms of its complex coverage of ethos, pathos and logos. To be more specific, when compared with other types of specialised persuasive discourse examined in the project (technical, academic and business), religious discourse is understood to be unique in the sense that it functionally covers all the components of Aristotelian appeal, including pathos (cf. Virtanen \& Halmari 2005: 5, who maintain that the emotional appeal to the audience "is not expected to be foregrounded in the socalled professional genres").

As a result, within the legitimation process, a powerful appeal to the audience and a sophisticated blend of persuasive strategies are built, and these, hand in hand, reinforce the credibility of the message. Such phenomena actually fall into the category of 'credibility boosters', i.e. particular communicative mechanisms that are employed to increase the credibility of the message (on credibility cf., e.g. Bhatia 1999, Hyland 2005). Dvorak (2013: 233), who devoted a number of his research papers to studying persuasion, understands a segment of text as a credibility booster provided "the message communicated was linked to what is perceived either generally or by the intended audience as a credible source" (ibid.: 233). He distinguishes three different aspects of credibility boosters that increase the persuasive potential in a number of doctrinal writings published by selected non-standard, distinctively non-trinitarian religious movements and cults (such as Jehovah's Witnesses, Scientologists or The Church of Jesus Christ of LatterDay Saints), viz. "references to scientific sources, references to long-established concepts whose credibility (or authority) has been forged by the denominations for centuries or even millennia, and novel concepts (usually denoted by neologisms but often linked to the long-established ones)" (ibid.: 234-239).

It follows that such a concept appears to be analogous to our findings above, including the emphasis placed on the authority of the Bible. Nevertheless, interestingly enough, unlike the corpus under examination in this paper, Dvorak's observations reveal a somewhat diverging aspect of the text profile: the data affiliated to the religious movements studied in his research typically manifest a "mixture of biblical principles and scientific data (or mentions of scientific sources, at least to sustain credibility of the religious concepts they promote" (ibid.: 234). Dvorak goes on to illustrate this tendency by examining texts by Jehovah's Witnesses and Mormons, which present medical evidence used to gain support for anti-transfusion, anti-abortion arguments and other controversial issues. In all the texts under his investigation, the scientific, hard-data approach is adopted, i.e. "statistical evidence" (Shen \& Bigsby 2013: 21).

In this respect, the paper definitely offers a novel view of the data studied. In summary, it seems that the mainstream Bible-anchored denominations prefer a 
different type of argumentation: the credibility of the sermons is consistently and consciously built upon a functional blend of the biblical (authority, facts, etc.) on the one hand, and on the personal (emotions, stories, etc.) on the other. The biblical support (this coincides with the sectarian religious movements) as if finds its contrasting, yet parallel, match of the dichotomy in a relatively more personal and less formal sort of evidence, such as the preacher's personal account or memory, someone else's experience, song lyrics, magazine articles, and the like. Thus, we see a peculiar merge of testimonial and analogical evidence. Another differing aspect would be the absence/presence of emphasis on the church's tradition and securing the role of clear context; whereas the traditional Christian denominations point out these two latter features and see them as crucial pillars of their faith, the sects tend to either ignore, background or obscure such references (cf. Dvorak 2013: 239-240).

To conclude, it has become obvious that the construal of persuasion in discourse is an extremely complex process, which should be approached not only from the position of the discourse itself, but also from the social and cognitive perspectives. This paper has primarily dealt with the genre-specific linguistic manifestation of persuasion in sermon titles and openings, highlighting several remarkable features related to persuasive strategies and perhaps opening vistas to further research. As anticipated theoretically, the character of religious communication in general is determined by its principal purpose: to present ideology, increase its credibility and subsequently persuade the audience. In order to achieve this, various linguistic realisations are employed; the resulting persuasive appeal (uniquely encompassing the Aristotelian concepts of ethos, pathos and logos) then helps to legitimise the set of Christian values via language, hence the intended purpose of religious discourse is fulfilled.

\section{Note}

This article is an output of the grant project 17-16195S Persuasion across Czech and English Specialised Discourses, which is supported by the Czech Science Foundation.

\section{References}

Allen, R. J. (1992) Preaching the Topical Sermon. Louisville: Westminster/John Knox Press.

Bell, A. (1997) 'Language style as audience design.' In: Coupland, N. and Jaworski, A. (eds) Sociolinguistics: A Reader and Coursebook. New York: St Martin's. 240-250.

Bhatia, V. K. (1999) 'Integrating products, processes, and participants in professional writing.' In: Candlin, C. N. and Hyland, K. (eds) Writing: Texts, Processes, and Practices. London, England: Longman. 21-39.

Bhatia, V. K. (1993) Analysing Genre: Language Use in Professional Settings. London: Longman. 
Bhatia, V. K. and Bremner, S. (eds) (2014) The Routledge Handbook of Language and Professional Communication. London: Routledge.

Carter, R. and Nash, W. (1990) Seeing through Language. A Guide to Styles of English Writing. Oxford: Oxford University Press.

Charles, H. B. (2015) 'About life, preaching, church and other stuff.' New York, 20122015. Online document. 14 July $2017<$ https:/www.hbcharlesjr.com/>.

Cialdini, R. B. (1993) Influence - The Psychology of Persuasion. Quill, William Morrow: New York.

Connor, U. and Moreno, A. (2005) 'Tertium comparationis: A vital component in contrastive rhetoric research.’ In: Bruthiaux, P., Atkinson, D., Eggington, W., Grabe, W. and Ramanathan, V. (eds) Directions in Applied Linguistics: Essays in Honor of Robert B. Kaplan. Multilingual Matters. England: Clevedon. 153-164.

Connor, U. (2004) 'Intercultural rhetoric research: Beyond texts.' Journal of English for Academic Purposes 3/4, 291-304.

Cotterell, P. and Turner, M. (1989) Linguistics and Biblical Interpretation. Downers Grove: InterVarsity Press.

Crystal, D. and Davy, D. (1969) Investigating English Style. London: Longman.

Dillard, J. P. and Pfau, M. (2002) The Persuasion Handbook: Developments in Theory and Practice. Thousand Oaks, CA: Sage Publications.

Dillard, J. P. and Seo, K. (2013) 'Affect and persuasion.' In: Dillard, J. P. and Shen, L. (eds) The Sage Book of Persuasion: Developments in Theory and Practice. London: Sage Publications. 150-166.

Dillard, J. P. and Shen, L. (eds) (2013) The SAGE Handbook of Persuasion: Developments in Theory and Practice. Thousand Oaks, CA: Sage Publications.

Dvorak, M. (2013) 'Means of increasing credibility in religious discourse.' Language and Communication Quarterly 2/4, 230-241.

Fee, G. D. and Stuart, D. (2003). How to Read the Bible for All its Worth. New York: Zondervan.

Garlock, J. (2002) Keys to Better Preaching. Broken Arrow: Faith Library Publications.

Ghadessy, M. (ed.) (1988) Registers of Written English. Situational Factors and Linguistic Features. London: Pinter Publishers.

Halliday, M. A. K. (1978) Language as Social Semiotics: The Social Interpretation of Language and Meaning. London: Edward Arnold.

Halmari, H. and Virtanen, T. (eds) (2005) Persuasion across Genres. Amsterdam and Philadelphia: John Benjamins.

Hogan, M. (2013) 'Persuasion in the rhetorical tradition.' In: Dillard, J. P. and Shen, L. (eds) The Sage Book of Persuasion: Developments in Theory and Practice. London: Sage Publications. 2-19.

Hyland, K. (2005) 'Stance and engagement: A model of interaction in academic discourse.' Discourse Studies 7/2, 173-192.

Mulholland, J. (1993) A Handbook of Persuasive Tactics: A Practical Language Guide. London and New York: Routledge.

Onions, C. T. (ed.) (1996) The Oxford Dictionary of English Etymology. Oxford: Oxford University Press.

Perloff, R. (2010) The Dynamics of Persuasion. Communication and Attitudes in the 21 $1^{\text {st }}$ Century. New York and London: Routledge.

Robinson, H. W. (2014) Biblical Preaching: The Development and Delivery of Expository Messages. New York: Baker Academic. 
Schiffrin, D., Tannen, D., Hamilton, H. (2001) The Handbook of Discourse Analysis. Malden, Oxford, Carlton: Blackwell.

Shen, L. and Bigsby, E. (2013) 'The effects of message features content, structure, and style.' In: Dillard, J. P. and Shen, L. (eds) The Sage Book of Persuasion: Developments in Theory and Practice. London: Sage Publications. 20-35.

Sperber, D., Clément, F., Heintz, C., Mascaro, O., Mercier, H., Origgi G. and Wilson, D. (2010) 'Epistemic vigilance.' Mind and Language 25, 359-393.

Swales, J. M. (1990) Genre Analysis. English in Academic and Research Settings. Cambridge: Cambridge University Press.

van Dijk, T. A. (1977) Text and Context. London: Longman.

van Dijk, T. A. (1998) Ideology. A Multidisciplinary Approach. London: Sage Publications. van Dijk, T. A. (2006) 'Discourse and manipulation.' Discourse \& Society 17/3, 359-383. van Leeuwen, T. (1996) 'The representation of social actors.' In: Caldas-Coulthard, C.-R. and Coulthard, M. (eds) Texts and Practices: Readings in Critical Discourse Analysis. London: Routledge. 32-70.

Virtanen, T. and Halmari, H. (2005) 'Persuasion across genres: Emerging perspectives.' In: Halmari, H. and Virtanen, T. (eds) Persuasion across Genres. Amsterdam and Philadelphia: John Benjamins. 3-24.

\section{Source}

REL-ENG. Sketch Engine. https://ske.fi.muni.cz/

Martin Adam is Associate Professor at the Department of English Language and Literature, Masaryk University, Brno. In his research, he has focused primarily on the theory of functional sentence perspective and religious discourse. Apart from a number of journal articles and book chapters, he is the author of $A$ Handbook of Functional Sentence Perspective (2008) and two monographs: Functional Macrofield Perspective (A Religious Discourse Analysis Based on FSP) (2009) and Presentation Sentences (Syntax, Semantics and FSP) (2013).

Address: doc. Mgr. Martin Adam, Ph.D., Department of English Language and Literature, Masaryk University, Poříčí 9, Brno 603 00, Czech Republic. [e-mail: martinadamcz@gmail.com] 
